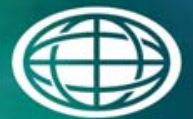

Savannah River

National Laboratory "m

OPERATED BY SAVANNAH RIVER NUCLEAR SOLUTIONS

\title{
Determining the Release of Radionuclides from Tank Waste Residual Solids
}

D. H. Miller, K. A. Roberts, K. M. L. Taylor-Pashow, D. T. Hobbs

September 2014

SRNL-STI-2014-00456, Revision 0 


\section{DISCLAIMER}

This work was prepared under an agreement with and funded by the U.S. Government. Neither the U.S. Government or its employees, nor any of its contractors, subcontractors or their employees, makes any express or implied:

1. warranty or assumes any legal liability for the accuracy, completeness, or for the use or results of such use of any information, product, or process disclosed; or

2. representation that such use or results of such use would not infringe privately owned rights; or

3. endorsement or recommendation of any specifically identified commercial product, process, or service.

Any views and opinions of authors expressed in this work do not necessarily state or reflect those of the United States Government, or its contractors, or subcontractors.

\section{Printed in the United States of America \\ Prepared for U.S. Department of Energy}


Keywords: high-level waste, closure, pore water, $p H$, redox potential

Retention: Permanent

\section{Determining the Release of Radionuclides from Tank Waste Residual Solids}

D. H. Miller

K. A. Roberts

K. M. L. Taylor-Pashow

D. T. Hobbs

September 2014

Prepared for the U.S. Department of Energy under 


\section{REVIEWS AND APPROVALS}

\section{AUTHORS:}

TECHNICAL REVIEW:

M. S. Hay, Advance Characterization \& Process, Reviewed per E7 2.60

APPROVAL:

F. M. Pennebaker, Manager

Date

Advanced Characterization \& Process

S.L. Marra, Manager

Date

Environmental \& Chemical Process Technology Research Programs

K. H. Rosenberger

Date

Waste Disposal Authority 


\section{ACKNOWLEDGEMENTS}

The authors thank M. E. Denham, D. I. Kaplan, and C. A. Langton for technical advice and assistance regarding the composition and preparation of grout solids used in high-level waste tank closures and synthetic infiltration waters and details concerning $\mathrm{E}_{\mathrm{h}}$ and $\mathrm{pH}$ controlling phases used at equilibrium conditions in performance assessment modeling. 


\section{EXECUTIVE SUMMARY}

Current practice for closing high-level waste tanks at the Savannah River Site involves removing as much of the HLW as possible, disconnecting all transfer lines and penetrations into the tanks, and filling the internal volume of the tanks with grout. Performance assessment modeling of the release of radionuclides from tank waste solids in these tanks indicated that plutonium, neptunium, technetium, and uranium are among the most likely risk drivers. Waste release testing was identified as needed to provide additional information regarding the residual waste solubility assumptions used in the F-Area and H-Area Tank Farm Performance Assessments' waste release models. The proposed testing was described generally in the Savannah River Site Liquid Waste Facilities Performance Assessment Maintenance Program FY2014 Implementation Plan. Savannah River Remediation LLC requested that the Savannah River National Laboratory perform such testing with available tank waste residuals after method development using surrogate materials. This document reports findings from the testing completed to date and recommendations for continued work.

Key findings based on experimental work completed to date with surrogate materials include the following.

- Pore water electron transfer potentials $\left(\mathrm{E}_{\mathrm{h}}\right)$ produced in these studies upon contact of synthetic infiltration water with surrogate tank closure solids are lower than those used in PA modeling. This suggests that in short-term experiments, kinetic controls on the $E_{h}$ values of the synthetic pore waters in contact with grout solids dominate over the equilibrium controls assumed in the PA waste release modeling.

- The zero head-space method appears viable for testing the release of radionuclides from solids under reducing conditions, but not under oxidizing conditions due to oxygen depletion.

- Researchers must account for the alkalinity and redox potential of the tank waste solids to ensure target $\mathrm{pH}$ and $\mathrm{E}_{\mathrm{h}}$ values will be achieved in radionuclide release testing.

- The addition of hydrogen peroxide will increase the $\mathrm{E}_{\mathrm{h}}$ potentials of OR3, but not OR2 pore water to about $+420 \mathrm{mV}$ and decrease the $\mathrm{pH}$ by about one $\mathrm{pH}$ unit. These changes are transitory due to the decomposition of peroxide in alkaline solutions.

- The addition of ozone increases the potentials of OR2 and OR3 pore waters above $+1000 \mathrm{mV}$ as long as excess ozone is present. The addition of ozone generates acid which lowers the $\mathrm{pH}$ of the pore OR2 and OR3 waters.

- Under moderate reducing conditions, the quantity of Pu and U dissolved from the surrogate Tank 18 solids increased in pore water solutions that feature less reducing $\mathrm{E}_{\mathrm{h}}$ and lower $\mathrm{pH}$ values.

- The presence of cement solids in the leaching tests generally reduced the dissolution of $\mathrm{Pu}$ and $\mathrm{U}$ from the surrogate Tank 18 solids. 
Based on the findings and conclusions summarized in this technical report, the authors recommend that leachate testing with surrogate materials be continued and finalized prior to initiating testing with actual waste residuals. Testing with actual tank waste solids would be expected to provide additional information regarding the residual waste solubility assumptions used in the Tank Farm Performance Assessments' waste release models. The following specific actions are recommended with respect to continued waste release testing.

- Reduce the lower quantifiable limit for detection of Pu in leachates by increasing the size of the aliquot and employ longer alpha counting times.

- Determine the effect, if any; of the syringe filter pore size on $\mathrm{Pu} / \mathrm{U}$ concentrations in leachates to ensure that the measured $\mathrm{Pu} / \mathrm{U}$ concentrations reflect only dissolved species.

- Complete experimental studies evaluating the use of ozone to increase oxidizing $E_{\mathrm{h}}$ potentials and the use of dithionite, sulfide and ferrous ion to increase reducing $E_{h}$ potentials so that surrogate pore waters have $\mathrm{E}_{\mathrm{h}}$ potentials at the targeted values.

- Test production of surrogate pore waters using only solid phases believed to be controlling the $\mathrm{pH}$ and $\mathrm{E}_{\mathrm{h}}$ at equilibrium conditions. 


\section{TABLE OF CONTENTS}

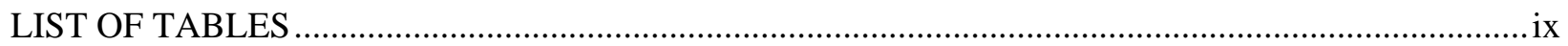

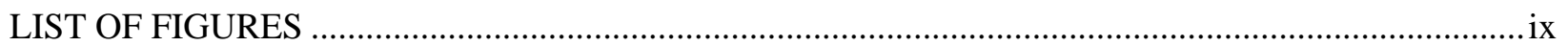

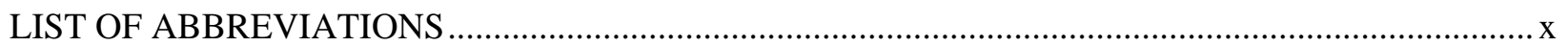

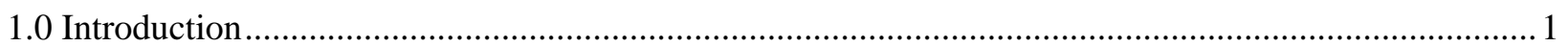

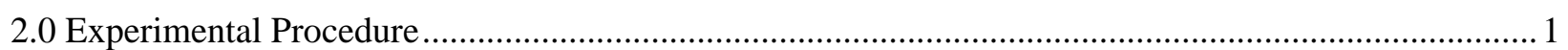

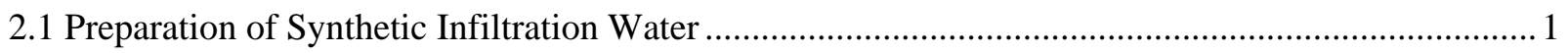

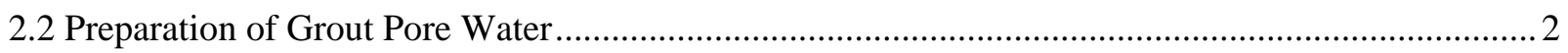

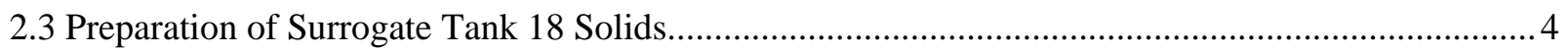

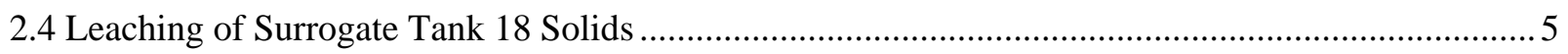

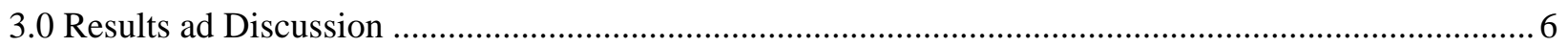

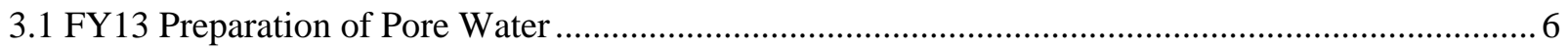

3.2 Zero Head Space Leaching Tests with Surrogate Tank 18 Solids ................................................ 6

3.3 Preparation of Pore Waters with Higher Reducing and Oxidizing Potentials................................ 10

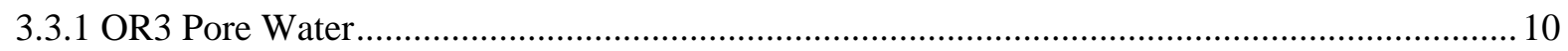

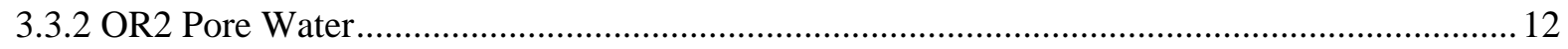

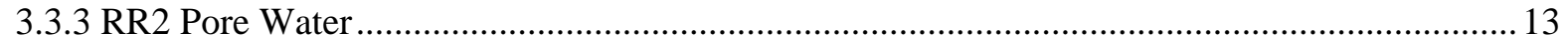

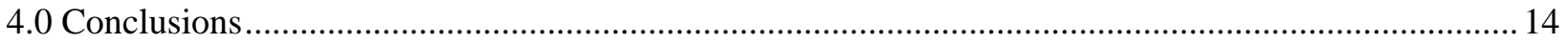

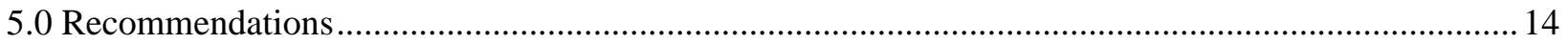

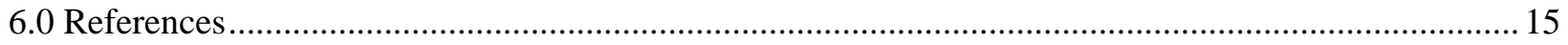




\section{LIST OF TABLES}

Table 2-1. Composition of Synthetic Infiltration Water Stock Solution................................................... 1

Table 2-2. Composition of Synthetic Infiltration Water ....................................................................... 2

Table 2-3. Target $\mathrm{E}_{\mathrm{h}}$ and $\mathrm{pH}$ for Each Pore Water Composition ............................................................ 2

Table 2-4. Composition of Tank 18 Solids Surrogate.......................................................................... 5

Table 3-1. pH Values During Zero Head Space Tests ......................................................................... 7

Table 3-2. $\mathrm{E}_{\mathrm{h}}$ Values During Zero Head Space Tests ......................................................................... 8

Table 3-3. Plutonium Leaching in Zero Head Space Tests................................................................... 9

Table 3-4. Uranium Leaching in Zero Head Space Tests .................................................................... 10

\section{LIST OF FIGURES}

Figure 2-1. Photograph of Synthetic Infiltration Water with Crushed \& Sieved CFS Solids..................... 3

Figure 2-2. Photograph of Experimental Equipment to Prepare Larger Bench-Scale Quantities of Pore

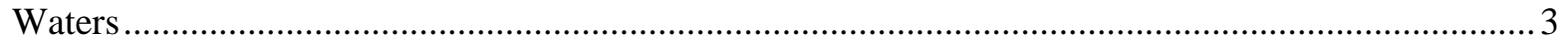

Figure 2-3. Photographs of Incubator Shaker Oven and Nested Glass Vials Inside Oven Used in Zero

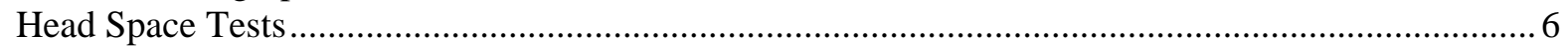

Figure 3-1. Plot of pH versus Date in the Preparation of the OR3 Pore Water ....................................... 12

Figure 3-2. Plot of $\mathrm{E}_{\mathrm{h}}$ versus Date in the Preparation of the OR3 Pore Water ......................................... 12 


\section{LIST OF ABBREVIATIONS}

$\begin{array}{ll}\text { SRNL } & \text { Savannah River National Laboratory } \\ \text { HLW } & \text { High-Level Waste } \\ \text { PA } & \text { Performance Assessment } \\ \text { SRR } & \text { Savannah River Remediation LLC } \\ \text { SRS } & \text { Savannah River Site } \\ \text { DOE } & \text { Department of Energy } \\ \text { CFS } & \text { Cement, Flyash \& Slag } \\ \text { FY } & \text { Fiscal Year } \\ \text { SIW } & \text { Synthetic Infiltration Water } \\ \text { RR2 } & \text { Reduced Region II } \\ \text { OR2 } & \text { Oxidizing Region II } \\ \text { OR3 } & \text { Oxidizing Region III } \\ \text { SCFH } & \text { Standard cubic feet per hour } \\ \text { LPM } & \text { Liters per minute } \\ E_{h} & \text { Electron transfer potential }\end{array}$




\subsection{Introduction}

Current practice for closing high-level waste (HLW) tanks at the Savannah River Site (SRS) involves removing as much of the HLW as possible, disconnecting all transfer lines and penetrations into the tanks, and filling the internal volume of the tanks with grout. Savannah River Remediation (SRR) closed Tanks 18 and 19 in 2012 and Tanks 5 and 6 in 2013. Performance assessment (PA) modeling of the release of radionuclides from tank waste solids in these tanks indicated that plutonium, neptunium, technetium, and uranium are among the most likely risk drivers. ${ }^{1}$ Due to the relatively high concentration of plutonium in Tank 18, the PA indicated that plutonium release was highest upon entering the oxidized region III, when the redox potential, $\mathrm{E}_{\mathrm{h}}$, is $+680 \mathrm{mV}$ and the $\mathrm{pH}$ is 9.2. At this stage, the dominant grout phase is calcite $\left(\mathrm{CaCO}_{3}\right)^{1}$

Waste release testing was identified as needed to provide additional information regarding the residual waste solubility assumptions used in the F-Area and H-Area Tank Farm Performance Assessments' waste release models. The proposed testing was described generally in the Savannah River Site Liquid Waste Facilities Performance Assessment Maintenance Program FY2014 Implementation Plan. ${ }^{2}$ This plan proposed that waste release experiments be performed with actual tank waste residuals after method development using surrogate materials. Thus, SRR requested that the Savannah River National Laboratory (SRNL) design and perform such testing with available tank waste samples. ${ }^{3}$ This document reports findings from this testing completed to date.

\subsection{Experimental Procedure}

\subsection{Preparation of Synthetic Infiltration Water}

A synthetic infiltration water (SIW) stock solution having the composition shown in Table 2-1 was prepared using reagent grade chemicals and ultrapure water (MilliQ Element). The SIW stock solution was then diluted 1000:1 to provide the infiltration water used in pore water preparations. Table 2-2 provides the composition of the SIW, which is based on the average chemical composition of groundwater from non-impacted wells screened within the water-table aquifer on the SRS ${ }^{4}$

Table 2-1. Composition of Synthetic Infiltration Water Stock Solution

\begin{tabular}{|c|c|}
\hline Chemical & Concentration (g/L) \\
\hline $\mathrm{CaCl}_{2} 2 \mathrm{H}_{2} \mathrm{O}$ & 3.68 \\
\hline $\mathrm{Na}_{2} \mathrm{SO}_{4}$ & 1.07 \\
\hline $\mathrm{KCl}$ & 0.40 \\
\hline $\mathrm{NaCl}$ & 2.65 \\
\hline $\mathrm{MgCl}_{2} 6 \mathrm{H}_{2} \mathrm{O}$ & 5.51 \\
\hline
\end{tabular}


Table 2-2. Composition of Synthetic Infiltration Water

\begin{tabular}{||c|c|}
\hline Component & Concentration \\
\hline $\mathrm{Na}^{+}$ & $1.39 \mathrm{mg} / \mathrm{L}$ \\
\hline $\mathrm{Cl}^{-}$ & $5.51 \mathrm{mg} / \mathrm{L}$ \\
\hline $\mathrm{Ca}^{2+}$ & $1.00 \mathrm{mg} / \mathrm{L}$ \\
\hline $\mathrm{Mg}^{2+}$ & $0.66 \mathrm{mg} / \mathrm{L}$ \\
\hline $\mathrm{K}^{+}$ & $0.21 \mathrm{mg} / \mathrm{L}$ \\
\hline $\mathrm{SO}_{4}{ }^{2-}$ & $0.73 \mathrm{mg} / \mathrm{L}$ \\
\hline $\mathrm{pH}^{2}$ & $4.5-4.9$ \\
\hline
\end{tabular}

\subsection{Preparation of Grout Pore Water}

Table 2-3 provides the target $\mathrm{E}_{\mathrm{h}}$ and $\mathrm{pH}$ values for the three pore waters to be used in the leaching tests. Note, all $\mathrm{E}_{\mathrm{h}}$ values are relative to the standard hydrogen electrode. A monolith representing the cement, flyash and slag (CFS) components of the grout used to fill Tanks 5, 6, 18 and 19 was prepared using 125 parts of Cement Type I/II, 210 parts of Slag Grade 100 and 363 parts of Fly Ash Class F. ${ }^{5}$ Sand was not added as a component of the monolith. Both flyash and slag contain significant quantities of silicon, which would serve as sources of silicon for dissolution into the grout pore water and the formation of silicate phases such as calcium silicate in the grout solids. Prior to contact with the infiltration water, the CFS monolith was broken into large pieces. Subsequently, the larger pieces were crushed and sieved through a 40 mesh $(420 \mu \mathrm{m})$ or 100 mesh $(149 \mu \mathrm{m})$ sieve.

Table 2-3. Target $\mathrm{E}_{\mathrm{h}}$ and $\mathrm{pH}$ for Each Pore Water Composition

\begin{tabular}{||c|c|c||}
\hline Test Condition & $\mathbf{E}_{\mathbf{h}} \mathbf{( m \mathbf { ) }}$ & $\mathbf{p H}$ \\
\hline Reduced Region II (RR2) & -470 & 11.1 \\
\hline Oxidized Region II (OR2) & +560 & 11.1 \\
\hline Oxidized Region III (OR3) & +680 & 9.2 \\
\hline
\end{tabular}

The general procedure to prepare the pore waters for solids leaching consisted of placing a measured quantity of the CFS solids in a glass vial or glass vessel and adding a measured quantity of the synthetic infiltration water. For this work the concentration of CFS solids in the SIW was fixed at $16.7 \mathrm{~g} / \mathrm{L}$. Figure 2-1 provides a photograph of a vial containing the synthetic infiltration water in contact with crushed and sieved CFS solids.

The $\mathrm{pH}$ measurements were obtained with one of the following, (1) an Accumet ${ }^{\mathrm{TM}}$ glass body pH probe in combination with an Accumet ${ }^{\mathrm{TM}}$ Model XL20 meter or (2) Fisher Scientific ${ }^{\mathrm{TM}}$ Accumet $^{\mathrm{TM}}$ Gel-filled Pencil -thin $\mathrm{pH}$ combination electrode connected to a Fisher Scientific ${ }^{\mathrm{TM}}$ Orion $^{\mathrm{TM}} 2$ Star or 4 Star meter. Fisher Scientific ${ }^{\mathrm{TM}} \mathrm{pH}$ buffers 4, 7, and 10 were used for calibration and calibration checks.

$E_{h}$ measurements were obtained with one of the following, (1) a Mettler-Toledo InLab ${ }^{\circledR}$ Redox Micro probe in combination with an Accumet ${ }^{\mathrm{TM}}$ Model XL20 meter or (2) Fisher Scientific ${ }^{\mathrm{TM}}$ Orion $^{\mathrm{TM}}$ Redox/ORP/Temp electrode, a Mettler Toledo $^{\mathrm{TM}}$ InLab redox combination electrode (ORP) in combination with an Extech ${ }^{\circledR}$ Instruments ORP meter. Thermo Scientific ${ }^{\mathrm{TM}}$ ORP Standard (Orion 967901) was used for calibration checks of the electrodes. All reported $E_{h}$ values are relative to the standard hydrogen electrode (SHE). 


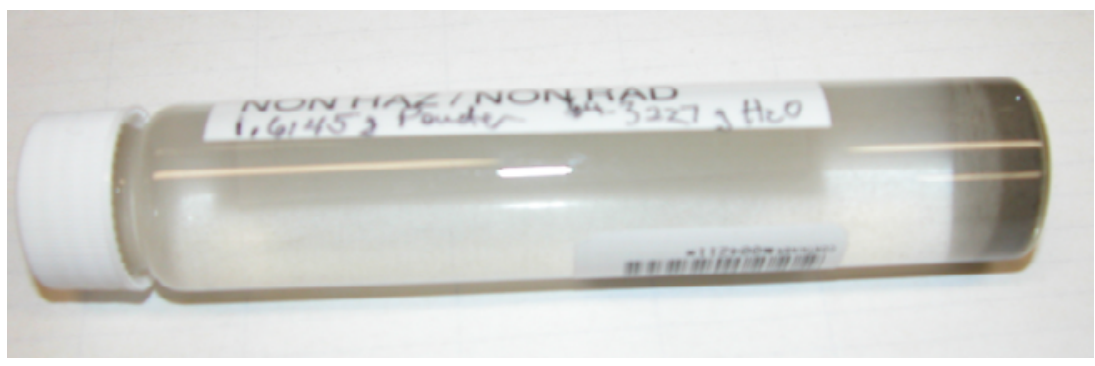

Figure 2-1. Photograph of Synthetic Infiltration Water with Crushed \& Sieved CFS Solids

For the RR2 pore water, argon was bubbled through the solution to limit the partial pressure of oxygen in the system. For the OR2 pore water, air that had been treated to remove carbon dioxide was bubbled through the solution to minimize the conversion of calcium hydroxide to calcium carbonate in the cement solids. For the OR3 pore water, air that had not been treated to remove carbon dioxide was bubbled through the solution to convert calcium hydroxide in the cement to calcium carbonate. Air flowrates were controlled at 1.2 standard cubic feet per hour (scfh). Figure 2-2 shows a photograph of the equipment used to prepare approximately one liter quantities of the pore waters.

Hydrogen peroxide and ozone were evaluated as chemical additives to increase the $\mathrm{E}_{\mathrm{h}}$ potentials for the OR2 and OR3 pore waters. Reagent grade $30 \mathrm{wt} \%$ hydrogen peroxide (Fisher Scientific) served as the source of hydrogen peroxide. Ozone was provided at a flow rate of 2 liters per minute (lpm) and a concentration of approximately 6.25\% by volume using an Ozone Solutions Model PS10 generator.

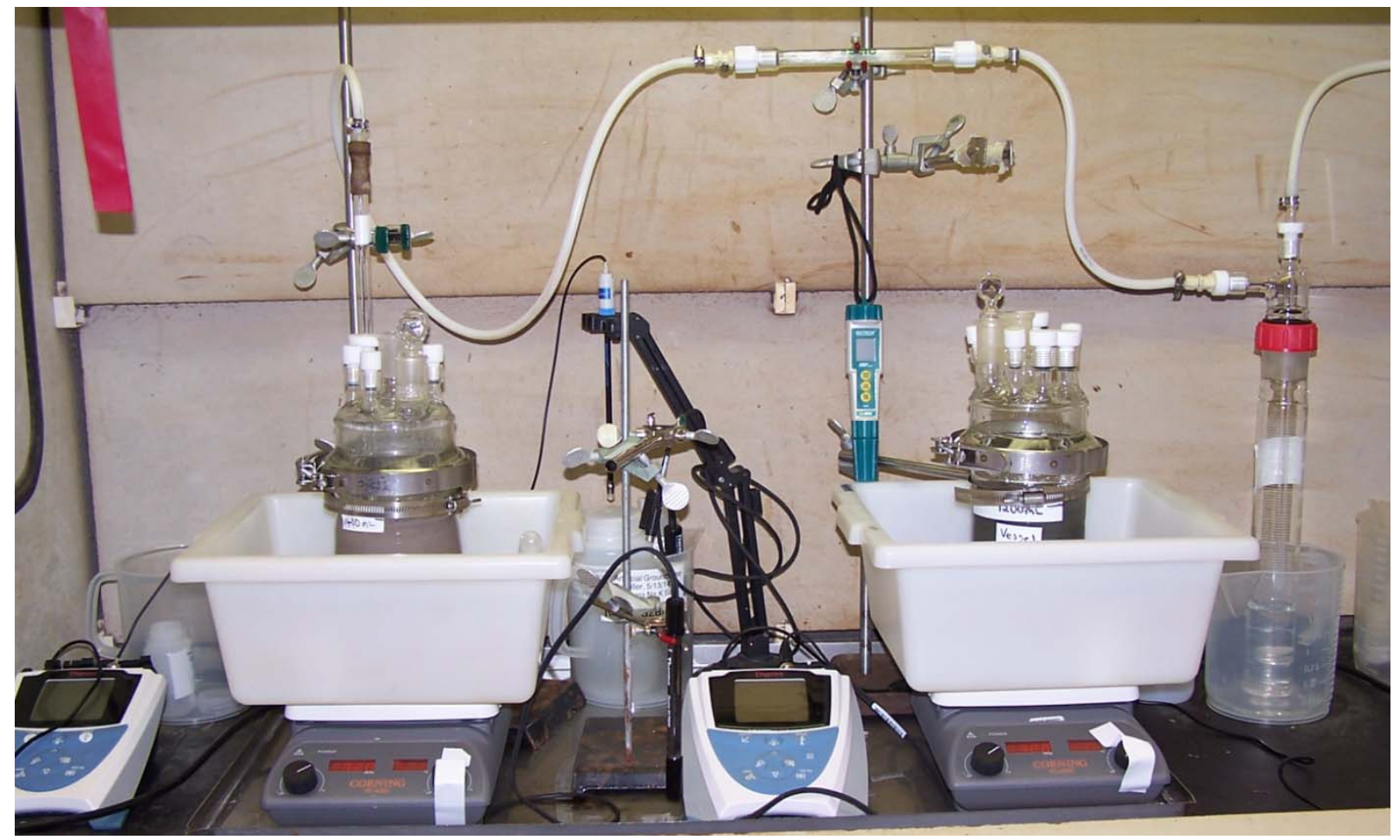

Figure 2-2. Photograph of Experimental Equipment to Prepare Larger Bench-Scale Quantities of Pore Waters 


\subsection{Preparation of Surrogate Tank 18 Solids}

A Tank 18 solids surrogate was prepared using reagent grade chemicals and spiked with radionuclides at the targeted amounts based on the average composition of several Tank 18 samples analyzed by SRNL. ${ }^{6,7}$ Table 2-4 provides the target and measured concentrations of the surrogate. Metal salts, as the respective nitrates, were dissolved in ultrapure water. Aluminum and silicon were added as sodium salts, sodium aluminate and sodium silicate, respectively. Plutonium(IV) and neptunium(V) were added as solutions in nitric acid from available stocks in SRNL. Uranium(VI) was added as uranyl nitrate hexahydrate, $\mathrm{UO}_{2}\left(\mathrm{NO}_{3}\right)_{2} \cdot 6 \mathrm{H}_{2} \mathrm{O}$. ${ }^{99} \mathrm{Tc}$ as technetium(VII) was added as a solution of ammonium pertechnetate available from commercial sources.

After addition of all component chemicals and radionuclides, a solution of $19.1 \mathrm{M}$ sodium hydroxide was slowly added to the nitric acid solution while mixing to precipitate the metals as metal hydroxides and hydrous metal oxides. Sodium hydroxide addition continued until the free hydroxide concentration in the supernatant was $0.1 \mathrm{M}$ based on calculated base requirement. The suspension was then heated to reflux for 24 hours to convert a fraction of aluminum and the silicon to sodium aluminosilicate. The suspension was cooled to ambient temperature. At that time, mixing was discontinued and the precipitated solids were allowed to gravity settle. Gravity settling did not produce a clear supernatant liquid above the solids. Thus, the suspension was filtered through a disposable Nalgene ${ }^{\circledR}$ filter with 0.45 -micron nylon membrane. The filtrate was collected and analyzed to determine the concentrations of $\mathrm{Pu}, \mathrm{Np}, \mathrm{U}$ and Tc that were not incorporated into the precipitated solids.

The concentrated solids mixture was diluted with an alkaline solution containing $0.01 \mathrm{M}$ sodium hydroxide and sodium carbonate at a volume equal to that of the decanted supernatant. After mixing for several hours, the mixture was again filtered to recover the solids. The supernatant dilution and filtration was repeated three additional times. The filtered wash solutions were collected and analyzed to determine the concentrations of $\mathrm{Pu}, \mathrm{Np}, \mathrm{U}$ and Tc that were removed by the wash solutions. After the final filtration the moist solids were air dried until a dry powder was achieved. The dried solids were lightly ground, transferred to a preweighed storage container and stored until used in leaching experiments.

Analysis of the filtrates and surrogate Tank 18 residual solids indicated that solids contained $\mathrm{Ca}, \mathrm{Fe}, \mathrm{Mg}$, $\mathrm{Mn}, \mathrm{U}$ and $\mathrm{Pu}$ at the target concentrations. The concentration of $\mathrm{Na}$ was about $33 \%$ higher than the target value and likely reflects the incorporation of sodium salts from the wash solution. The concentrations of $\mathrm{Al}, \mathrm{Si}, \mathrm{Np}$, and Tc were below the target concentrations. The low concentrations of $\mathrm{Np}$ and Tc, added as $\mathrm{NpO}_{2}{ }^{+}$and $\mathrm{TcO}_{4}{ }^{-}$, respectively, were not unexpected given the solubilities of the neptunyl and pertechnetate species. 
Table 2-4. Composition of Tank 18 Solids Surrogate

\begin{tabular}{|c|c|c|}
\hline Component & $\begin{array}{c}\text { Target } \\
\text { Concentration } \\
\text { (wt \%) }\end{array}$ & $\begin{array}{c}\text { Measured } \\
\text { Concentration }^{\mathrm{a}} \\
(\mathrm{wt} \%)\end{array}$ \\
\hline $\mathrm{Al}$ & 15.2 & $11.3+1.2$ \\
\hline $\mathrm{Ca}$ & 2.69 & $2.69+0.28$ \\
\hline $\mathrm{Fe}$ & 8.00 & $7.90 \pm 0.83$ \\
\hline $\mathrm{Mg}$ & 2.00 & $2.09+0.22$ \\
\hline $\mathrm{Mn}$ & 1.09 & $1.04+0.11$ \\
\hline $\mathrm{Na}$ & 4.48 & $5.96 \pm 0.62$ \\
\hline $\mathrm{Si}$ & 3.96 & $0.22+0.038$ \\
\hline $\mathrm{U}$ & 2.37 & $\begin{array}{c}2.39 \pm 0.24 \\
2.50 \pm 0.50^{\mathrm{b}}\end{array}$ \\
\hline $\mathrm{Pu}-239 / 240$ & 0.0160 & $0.0160+0.0009$ \\
\hline Np-237 & 7.53E-04 & bql \\
\hline Тс-99 & $2.60 \mathrm{E}-04$ & bql \\
\hline
\end{tabular}

\subsection{Leaching of Surrogate Tank 18 Solids}

Leaching experiments were performed using the prepared Tank 18 solids surrogate and prepared pore waters representing Reduced Region II (RR2), Oxidized Region II (OR2), and Oxidized Region III (OR3). Experiments utilized zero-head space vials holding approximately $40 \mathrm{~mL}$ of pore water. For each experiment $1.2 \mathrm{~g}$ of the Tank 18 solids surrogate was added to the vial followed by the desired pore water. The vials were then capped, leaving zero head-space, and placed into a $25{ }^{\circ} \mathrm{C}$ shaker oven for agitation at $175 \mathrm{rpm}$. Figure 2-3 shows photographs of the shaker oven and the glass vials nested on the shaker table inside the oven.

A separate vial was prepared for each sampling event since air is introduced into the head space of the vial once the vial is opened and a sample is removed. Tests were conducted in duplicate for each pore water, one set using filtered pore water samples, and the second set including some of the grout solids used for preparing the pore water. Samples from the RR2 and OR3 experiments were removed after 1, 2, 3 , and 4 weeks. Samples from the OR2 experiments were removed after 1 day and 1 week of contact.

The $\mathrm{pH}$ and $\mathrm{E}_{\mathrm{h}}$ of the pore waters were measured just prior to starting the experiments, and then again at each of the sampling events. For sampling, approximately $10 \mathrm{~mL}$ of solution was filtered through a 0.1- $\mu \mathrm{m}$ PVDF syringe filter. A 9-mL aliquot of this filtrate was acidified with $1 \mathrm{~mL}$ of $5 \mathrm{M}$ nitric acid. Aliquots of the acidified filtrate were submitted for ICP-MS and PuTTA analyses to determine the U and Pu concentrations, respectively. 

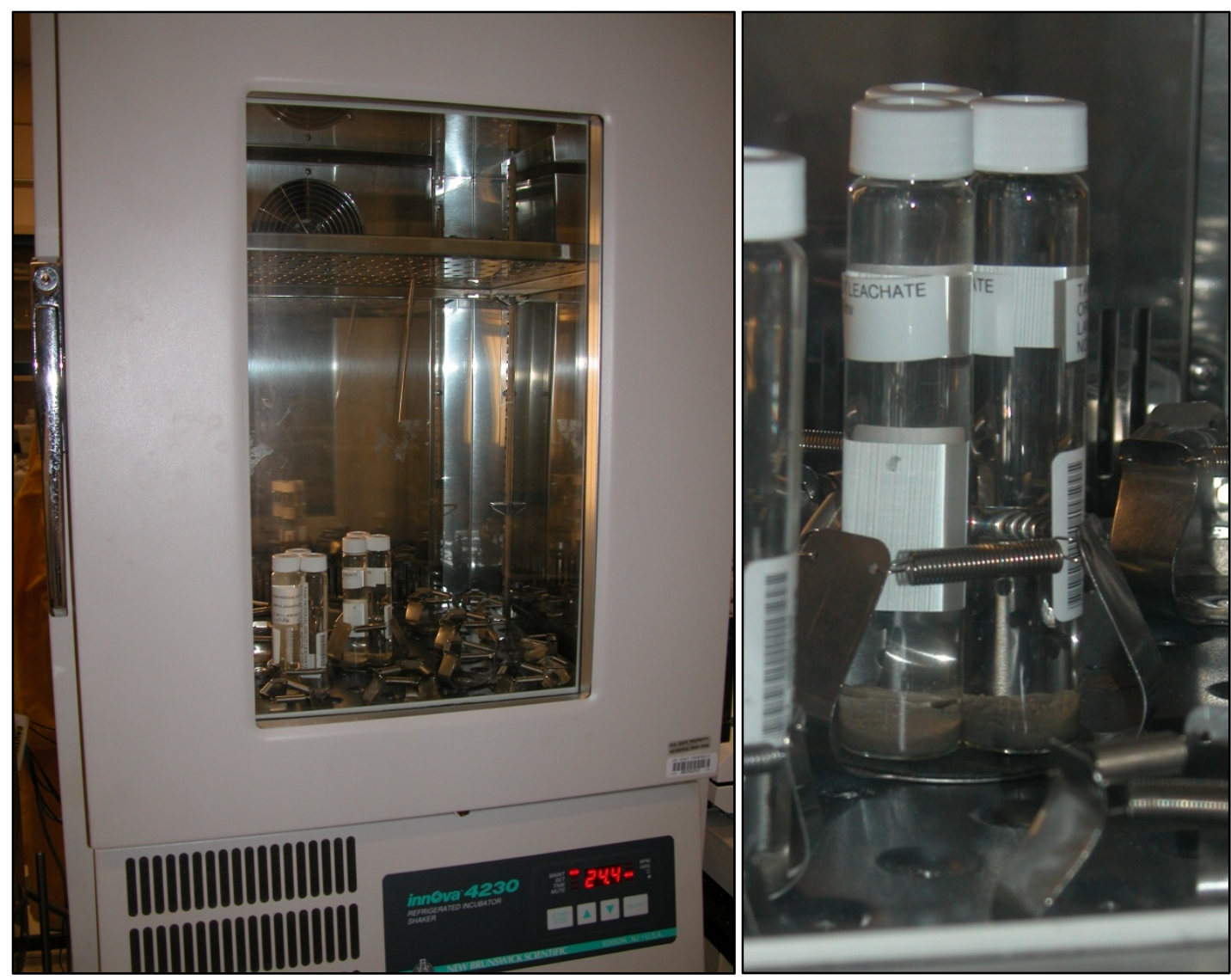

Figure 2-3. Photographs of Incubator Shaker Oven and Nested Glass Vials Inside Oven Used in Zero Head Space Tests

\subsection{Results ad Discussion}

\subsection{FY13 Preparation of Pore Water}

FY2013 testing produced pore waters having the desired $\mathrm{pH}$ values, but with $\mathrm{E}_{\mathrm{h}}$ values significantly lower than the targeted values (see Tables 3-1 and 3-2). For example, the RR2 pore water measured to have a $\mathrm{pH}$ of 11.40 and an $\mathrm{E}_{\mathrm{h}}$ of $-156 \mathrm{mV}$ versus the target values of 11.1 and $-470 \mathrm{mV}$, respectively. For the OR2 and OR3 pore waters, the $\mathrm{pH}$ measured 11.19 and 9.59 versus target values of 11.1 and 9.2, respectively. The measured and target $E_{h}$ values for the oxidizing pore waters, OR2 and OR3, were +110 vs. $+480 \mathrm{mV}$ and +165 vs. $+560 \mathrm{mV}$, respectively. Based on these findings, pore water $\mathrm{E}_{\mathrm{h}}$ potentials produced in these studies are lower than those used in PA modeling. This suggests that in short-term experiments as described in this document, kinetic controls on the $E_{h}$ values of the synthetic pore waters in contact with grout solids dominate over the equilibrium controls assumed in the PA waste release modeling.

\subsection{Zero Head Space Leaching Tests with Surrogate Tank 18 Solids}

Although the pore waters did not meet the target $E_{h}$ values, leaching experiments were carried out to measure the release of plutonium and uranium from the surrogate Tank 18 solids. Evaluation of the release of neptunium and technetium was not possible since the concentrations of ${ }^{237} \mathrm{~Np}$ and ${ }^{99} \mathrm{Tc}$ in the surrogate Tank 18 solids fell below their respective quantifiable limits. All of the leaching tests used a zero-head space methodology to limit contact of air during the testing. 
Table 3-1 provides the target $\mathrm{pH}$, as-prepared $\mathrm{pH}$, initial $\mathrm{pH}$, and $\mathrm{pH}$ measured after 1, 2, 3 and 4 weeks of contact with the surrogate Tank 18 solids. Table 3-2 provides the target $\mathrm{E}_{\mathrm{h}}$, as-prepared $\mathrm{E}_{\mathrm{h}}$, initial $\mathrm{E}_{\mathrm{h}}$, and $E_{h}$ measured after 1, 2, 3 and 4 weeks of contact with the surrogate Tank 18 solids. Note, the initial $\mathrm{pH}$ and $\mathrm{E}_{\mathrm{h}}$ values are those measured for the solution prior to the addition of the surrogate Tank 18 solids. From the time that the pore waters were prepared to when they were used in the leaching tests, the $\mathrm{pH}$ values increased and the $\mathrm{E}_{\mathrm{h}}$ values became more reducing. In the case of the two oxidizing pore waters, OR2 and OR3, dissolved oxygen is likely being consumed resulting in more reducing potentials.

Over the leaching contact period of one to four weeks, the $\mathrm{pH}$ and the $\mathrm{E}_{\mathrm{h}}$ of the RR2 pore water exhibited very little change. Over the one week contact time the $\mathrm{pH}$ and $\mathrm{E}_{\mathrm{h}}$ values of the OR2 pore waters exhibited little change in $\mathrm{pH}$ and a small decrease in $\mathrm{E}_{\mathrm{h}}$ indicating slightly more reducing conditions. For the leaching test with the OR3 waters, the $\mathrm{pH}$ and $\mathrm{E}_{\mathrm{h}}$ values did not change appreciably. The $\mathrm{pH}$ and $\mathrm{E}_{\mathrm{h}}$ values are fairly consistent across the 4-week time period for the RR2 and OR3 tests suggesting that steady-state conditions had been achieved after about one week. This confirms that the zero head space methodology can be used to maintain reducing redox potential for up to four weeks.

Table 3-1. pH Values During Zero Head Space Tests

\begin{tabular}{|c|c|c|c|c|c|c|c||}
\hline $\begin{array}{c}\text { Test } \\
\text { Condition }\end{array}$ & $\begin{array}{c}\text { Target } \\
\mathbf{p H}\end{array}$ & $\begin{array}{c}\text { As- } \\
\text { Prepared } \\
\mathbf{p H}\end{array}$ & $\begin{array}{c}\text { Average } \\
\text { Initial } \\
\mathbf{p H}\end{array}$ & $\begin{array}{c}\text { Average } \\
\mathbf{1} \text { week } \\
\mathbf{p H}\end{array}$ & $\begin{array}{c}\text { Average } \\
\mathbf{2} \text { week } \\
\mathbf{p H}\end{array}$ & $\begin{array}{c}\text { Average } \\
\mathbf{3} \text { week } \\
\mathbf{p H}\end{array}$ & $\begin{array}{c}\text { Average } \\
\mathbf{4} \text { week } \\
\mathbf{p H}\end{array}$ \\
\hline RR2 & 11.1 & 11.19 & 11.92 & 11.40 & 11.40 & 11.39 & 11.26 \\
\hline $\begin{array}{c}\text { RR2 with } \\
\text { CFS solids }\end{array}$ & 11.1 & 11.19 & 11.87 & 11.62 & 11.72 & 11.74 & 11.58 \\
\hline OR2* & 11.1 & 11.40 & 11.64 & $11.51^{*}$ & $11.40^{*}$ & $\mathrm{~nm}$ & $\mathrm{~nm}$ \\
\hline $\begin{array}{c}\text { OR2 with } \\
\text { CFS solids* }\end{array}$ & 11.1 & 11.40 & 11.67 & $11.62^{*}$ & $11.64^{*}$ & $\mathrm{~nm}$ & $\mathrm{~nm}$ \\
\hline OR3 & 9.2 & 9.58 & 10.31 & 10.58 & 10.68 & 10.59 & 10.53 \\
\hline $\begin{array}{c}\text { OR3 with } \\
\text { CFS solids }\end{array}$ & 9.2 & 9.58 & 10.05 & 10.61 & 10.83 & 10.83 & 10.83 \\
\hline
\end{tabular}

${ }^{1} \mathrm{pH}$ prior to addition of surrogate Tank 18 solids

*OR2 experiments are after contact with pore waters for 1 day and 1 week, respectively. $\mathrm{nm}=$ not measured 
Table 3-2. $E_{h}$ Values During Zero Head Space Tests

\begin{tabular}{|c|c|c|c|c|c|c|c|}
\hline $\begin{array}{c}\text { Test } \\
\text { Condition }\end{array}$ & $\begin{array}{c}\text { Target } \\
E_{h}(\mathbf{m V})\end{array}$ & $\begin{array}{c}\text { As } \\
\text { Prepared } \\
E_{h}(m V)\end{array}$ & $\begin{array}{c}\text { Average } \\
{\text { Initial } E_{h}}_{(\mathrm{mV})^{1}}\end{array}$ & $\begin{array}{c}\text { Average } \\
1 \text { week } E_{h} \\
(\mathrm{mV})\end{array}$ & $\begin{array}{c}\text { Average } \\
2 \text { week } E_{h} \\
(\mathrm{mV})\end{array}$ & $\begin{array}{c}\text { Average } \\
3 \text { week E } \\
(\mathrm{mV})\end{array}$ & $\begin{array}{c}\text { Average } \\
4 \text { week E } \\
(\mathrm{mV})\end{array}$ \\
\hline RR2 & -470 & -156 & -215 & -176 & -203 & -214 & -189 \\
\hline $\begin{array}{l}\text { RR2 with } \\
\text { CFS solids }\end{array}$ & -470 & -156 & -207 & -211 & -222 & -246 & -215 \\
\hline OR2* & +560 & +110 & -43 & $-183 *$ & $-201 *$ & $\mathrm{~nm}$ & $\mathrm{~nm}$ \\
\hline $\begin{array}{l}\text { OR2 with } \\
\text { CFS } \\
\text { solids* }\end{array}$ & +560 & +110 & -93 & $-197^{*}$ & $-224^{*}$ & $\mathrm{~nm}$ & $\mathrm{~nm}$ \\
\hline OR3 & +680 & +165 & -36 & -141 & -157 & -142 & -138 \\
\hline $\begin{array}{l}\text { OR3 with } \\
\text { CFS solids }\end{array}$ & +680 & +165 & -13 & -141 & -162 & -166 & -142 \\
\hline
\end{tabular}

${ }^{1} \mathrm{E}_{\mathrm{h}}$ prior to addition of surrogate Tank 18 solids

*OR2 experiments are after contact with pore waters for 1 day and 1 week, respectively.

$$
\mathrm{nm}=\text { not measured }
$$

Tables 3-3 and 3-4 provide the measured plutonium and uranium concentrations in the leach solutions for selected test conditions and contact times. Of the 22 experimental measurements for plutonium concentration, seven of the results proved below the quantifiable limit. The values are also close to the "more realistic" solubility of amorphous plutonium oxide, 3.2E-11 molar as reported by Denham. ${ }^{1}$ These results indicate that a larger sample aliquot should be used and perhaps longer alpha counting times to provide a lower quantification limit for the plutonium measurements.

For each pore water test, there is no discernible trend in the concentration of plutonium with contact time. Comparison of the RR2 and OR3 results suggests that the more oxidizing and lower pH conditions of the OR3 test may favor a higher plutonium concentration. However, the small number of sample results above the quantifiable limit for these two tests provides a high uncertainty to this statement. The measured plutonium concentrations are very similar for the RR2 and OR2 tests after 2 weeks and 1 week of contact, respectively. This finding is not unexpected since both the $\mathrm{E}_{\mathrm{h}}$ and $\mathrm{pH}$ conditions are very similar for these pore water tests. 
Table 3-3. Plutonium Leaching in Zero Head Space Tests

\begin{tabular}{|c|c|c|c|c|c|c|c|c|}
\hline $\begin{array}{c}\text { Test } \\
\text { Condition }\end{array}$ & $\begin{array}{l}\text { Average } \\
E_{h}(m V)\end{array}$ & $\begin{array}{c}\text { Average } \\
\text { pH }\end{array}$ & $\begin{array}{c}\text { Pu] M } \\
\text { after 1 } \\
\text { week } \\
\text { contact }^{1} \\
\end{array}$ & $\begin{array}{c}\text { \% Pu } \\
\text { Leached } \\
(1 \text { week) }\end{array}$ & $\begin{array}{c}\text { Pu] M } \\
\text { after } 2 \\
\text { weeks } \\
\text { contact } \\
\end{array}$ & $\begin{array}{c}\text { \% Pu } \\
\text { Leached } \\
\text { (2 weeks) }\end{array}$ & $\begin{array}{c}\mathrm{Pu}] \mathrm{M} \\
\text { after } 4 \\
\text { weeks } \\
\text { contact } \\
\end{array}$ & $\begin{array}{c}\text { \% Pu } \\
\text { Leached } \\
\text { (4 weeks) }\end{array}$ \\
\hline RR2 & -195 & 11.36 & $\begin{array}{c}1.26 \mathrm{E}-10 \\
(3.96 \mathrm{E}-11)\end{array}$ & $\begin{array}{c}0.00077 \\
(0.00023)\end{array}$ & $4.21 \mathrm{E}-10$ & 0.00246 & $<3.11 \mathrm{E}-10$ & $<0.00192$ \\
\hline $\begin{array}{l}\text { RR2 w/ } \\
\text { solids }\end{array}$ & -223 & 11.66 & $6.46 \mathrm{E}-11^{2}$ & $0.00040^{2}$ & $<1.40 \mathrm{E}-10$ & $<0.00083$ & $<4.06 \mathrm{E}-10$ & $<0.00252$ \\
\hline OR2* & -192 & 11.45 & $\begin{array}{c}1.96 \mathrm{E}-10 \\
(1.80 \mathrm{E}-10)\end{array}$ & $\begin{array}{c}0.00119 \\
(0.00108)\end{array}$ & $<1.04 \mathrm{E}-10$ & $<0.00063$ & $\mathrm{~nm}$ & $\mathrm{~nm}$ \\
\hline $\begin{array}{l}\text { OR2 w/ } \\
\text { solids* }\end{array}$ & -210 & 11.63 & $1.80 \mathrm{E}-10^{2}$ & $0.00110^{2}$ & 8.39E-11 & 0.00051 & $\mathrm{~nm}$ & $\mathrm{~nm}$ \\
\hline OR3 & -144 & 10.59 & $\begin{array}{c}1.25 \mathrm{E}-09 \\
(7.97 \mathrm{E}-11)\end{array}$ & $\begin{array}{c}0.00754 \\
(0.00046)\end{array}$ & 7.38E-10 & 0.00441 & $<9.88 \mathrm{E}-10$ & $<0.00610$ \\
\hline $\begin{array}{c}\text { OR3 w/ } \\
\text { solids }\end{array}$ & -153 & 10.77 & $\begin{array}{c}5.40 \mathrm{E}-10 \\
(2.77 \mathrm{E}-10)\end{array}$ & $\begin{array}{c}0.00323 \\
(0.00157)\end{array}$ & $2.23 \mathrm{E}-10$ & 0.00134 & 8.33E-10 & 0.00487 \\
\hline
\end{tabular}

${ }^{1}$ Values are averages of results from replicate tests with standard deviations shown in parenthesis.

${ }^{2}$ Duplicate tests were performed, but only one sample was above the detection limit.

*OR2 experiments are after contact with pore waters for 1 day and 1 week, respectively.

$$
\mathrm{nm}=\text { not measured }
$$

Determinations of the uranium concentrations were obtained after 1, 2 and 4 weeks of contact for the RR2 and OR3 pore water tests and one day and one week of contact for the OR2 pore water tests. The quantity of uranium dissolved from the surrogate Tank 18 solids was very similar for the RR2 and OR2 pore waters. This is the expected trend given the similar $\mathrm{E}_{\mathrm{h}}$ and $\mathrm{pH}$ conditions for these two pore water tests. Note also, that the dissolution of uranium was lower for both pore waters in the presence of the CFS solids. The test mixtures for both pore tests with the CFS solids are about $20-25 \mathrm{mV}$ lower than those in the absence of the CFS solids. This trend may reflect the influence of the redox potential on the solubility of uranium in these solutions.

For the OR3 test, the measured uranium concentrations are considerably higher than those measured in the RR2 and OR2 tests. This finding is not unexpected since the lower $\mathrm{pH}$ and likely higher bicarbonate/carbonate concentrations would favor dissolution of uranium from the surrogate Tank 18 solids. The much lower percentage of uranium leached for the OR3 test containing CFS solids cannot be attributed to the redox potential since the $\mathrm{E}_{\mathrm{h}}$ values are very similar. The CFS solids may be buffering the dissolved bicarbonate/carbonate to a lower value due to the presence of excess calcium and, thereby limiting complexing of uranium by carbonate. 
Table 3-4. Uranium Leaching in Zero Head Space Tests

\begin{tabular}{|c|c|c|c|c|c|c|c|c|}
\hline $\begin{array}{c}\text { Test } \\
\text { Condition }\end{array}$ & $\begin{array}{l}\text { Average } \\
E_{h}(m V)\end{array}$ & $\begin{array}{c}\text { Average } \\
\text { pH }\end{array}$ & $\begin{array}{c}\mathrm{CU}] \mathrm{M} \\
\text { after } 1 \\
\text { week } \\
\text { contact }^{1} \\
\end{array}$ & $\begin{array}{c}\% \mathrm{U} \\
\text { Leached } \\
\text { (1 week) }^{1}\end{array}$ & $\begin{array}{c}\text { [U] M } \\
\text { after } 2 \\
\text { weeks } \\
\text { contact } \\
\end{array}$ & $\begin{array}{c}\% \text { U } \\
\text { Leached } \\
\text { (2 weeks) }\end{array}$ & $\begin{array}{c}\text { [U] M } \\
\text { after } 4 \\
\text { weeks } \\
\text { contact } \\
\end{array}$ & $\begin{array}{c}\% \mathrm{U} \\
\text { Leached } \\
\text { (4 weeks) }\end{array}$ \\
\hline RR2 & -195 & 11.36 & $\begin{array}{c}5.69 \mathrm{E}-06 \\
(5.28 \mathrm{E}-07)\end{array}$ & $\begin{array}{c}0.216 \\
(0.016)\end{array}$ & 7.66E-06 & 0.279 & 4.67E-06 & 0.179 \\
\hline $\begin{array}{l}\text { RR2 w/ } \\
\text { solids }\end{array}$ & -223 & 11.66 & $\begin{array}{c}2.93 \mathrm{E}-06 \\
(1.68 \mathrm{E}-06)\end{array}$ & $\begin{array}{c}0.113 \\
(0.065)\end{array}$ & 2.43E-06 & 0.090 & 4.14E-06 & 0.160 \\
\hline OR2* & -192 & 11.45 & $\begin{array}{l}1.06 \mathrm{E}-05^{*} \\
(3.90 \mathrm{E}-06)\end{array}$ & $\begin{array}{l}0.402 * \\
(0.142)\end{array}$ & $5.88 \mathrm{E}-06 *$ & $0.224 *$ & $\mathrm{~nm}$ & $\mathrm{~nm}$ \\
\hline $\begin{array}{l}\text { OR2 w/ } \\
\text { solids* }\end{array}$ & -210 & 11.63 & $\begin{array}{l}2.50 \mathrm{E}-06 * \\
(1.72 \mathrm{E}-07)\end{array}$ & $\begin{array}{l}0.096^{*} \\
(0.007)\end{array}$ & $2.22 \mathrm{E}-06^{*}$ & $0.084^{*}$ & $\mathrm{~nm}$ & $\mathrm{~nm}$ \\
\hline OR3 & -144 & 10.59 & $\begin{array}{c}7.26 \mathrm{E}-05 \\
(1.85 \mathrm{E}-05)\end{array}$ & $\begin{array}{c}2.73 \\
(0.703)\end{array}$ & 8.85E-05 & 3.30 & 7.64E-05 & 2.95 \\
\hline $\begin{array}{l}\text { OR3 w/ } \\
\text { solids }\end{array}$ & -153 & 10.77 & $\begin{array}{c}2.10 \mathrm{E}-05 \\
(2.13 \mathrm{E}-06)\end{array}$ & $\begin{array}{c}0.789 \\
(0.055)\end{array}$ & 2.11E-05 & 0.795 & $1.20 \mathrm{E}-05$ & 0.440 \\
\hline
\end{tabular}

${ }^{1}$ Values are averages of results from replicate tests with standard deviations shown in parenthesis. *OR2 experiments are after contact with pore waters for 1 day and 1 week.

$\mathrm{nm}=$ not measured

\subsection{Preparation of Pore Waters with Higher Reducing and Oxidizing Potentials}

In FY2013, the $E_{h}$ values for the pore waters were considerably lower than that of the target values as provided in Table 2-3. Thus, FY2014 testing focused on identifying conditions that would result in pore waters having $E_{h}$ values closer to that of the target values. For oxidizing pore waters (OR2/OR3), the strategy was to determine if an increase in the partial pressure of oxygen or addition of stronger oxidants (e.g., peroxide or ozone) would produce the targeted $E_{h}$ values in the presence of CFS solids. A similar strategy was planned for reducing pore water (RR2), except one would add a reducing agent (e.g., dithionite, $\mathrm{Fe}^{2+}$, sulfide).

\subsubsection{OR3 Pore Water}

For OR3, the target $\mathrm{E}_{\mathrm{h}}$ is $+680 \mathrm{mV}$ and $\mathrm{pH}$ is 9.2. A total of 1.4 liters of the SIW (pH 6.62 and $\mathrm{E}_{\mathrm{h}}+508$ $\mathrm{mV}$ ) and 23.3 grams of large pieces removed from a CFS monolith were placed in the glass vessel as shown on the right side of Figure 3-1. Upon addition of the CFS solids, the $\mathrm{pH}$ measured 10.5 and the $\mathrm{E}_{\mathrm{h}}$ measured $+205 \mathrm{mV}$. Initially the apparatus was opened to the room air allowing oxygen to freely contact the mixture of the SIW and CFS solids. Periodic measurements of the $\mathrm{pH}$ and $\mathrm{E}_{\mathrm{h}}$ were made and recorded. Mixing was stopped during the off-shift time periods, but the vessel remained open to the laboratory atmosphere. During the initial 8 days of contact, the $\mathrm{pH}$ decreased to 9.88 and the $\mathrm{E}_{\mathrm{h}}$ decreased to about $+150 \mathrm{mV}$.

After 8 days, the CFS solids were removed from the vessel, ground to a fine powder, seived through a 100 mesh sieve, and returned to the vessel. Over the next 13 days, the $\mathrm{pH}$ and $\mathrm{E}_{\mathrm{h}}$ did not change appreciably. Thus, it was decided to bubble air through the mixture to ensure the solution was saturated in oxygen. Air was bubbled through the stirred mixture at a rate of 1.2 standard cubic feet per hour (SCFH). Agitation and air sparging were stopped during off-shift time periods. 
Upon bubbling air into the mixture, the $\mathrm{E}_{\mathrm{h}}$ immediately increased to about $+225 \mathrm{mV}$ and remained at this potential over the next 13 days. During the 13-day time period, the $\mathrm{pH}$ of the mixture decreased from 9.8 to about 8.1. Since the $\mathrm{E}_{\mathrm{h}}$ had appeared to reach steady-state condition, it was decided to see if the $\mathrm{E}_{\mathrm{h}}$ could be increased by the addition of hydrogen peroxide. Small additions of $30 \mathrm{wt} \%$ hydrogen peroxide to provide 0.1 - 10 millimolar concentration of peroxide did not exhibit any effect on the $\mathrm{E}_{\mathrm{h}}$. However, upon the addition of 2.0 grams of hydrogen peroxide $(100 \mathrm{mM})$, the $E_{h}$ immediately increased to +300 $\mathrm{mV}$. The higher $\mathrm{E}_{\mathrm{h}}$ persisted for a few minutes and then decreased reaching $+220 \mathrm{mV}$ after 3.5 hours and $+202 \mathrm{mV}$ the following morning. The $\mathrm{E}_{\mathrm{h}}$ remained at about $+200 \mathrm{mV}$ for the next four days. During this time the $\mathrm{pH}$ of the mixture ranged between 8.28 to 8.49 .

The addition of another 2.0 grams of hydrogen peroxide $(100 \mathrm{mM})$ increased the $\mathrm{E}_{\mathrm{h}}$ to $+430 \mathrm{mV}$ and maintained an $E_{h}$ at or above $+400 \mathrm{mV}$ for $4-5$ hours. After 24 hours, the $E_{h}$ measured $+310 \mathrm{mV}$ and after about 33 hours the $\mathrm{E}_{\mathrm{h}}$ had decreased to $+226 \mathrm{mV}$. The $\mathrm{pH}$ remained unchanged in the range of 8.19 to 8.47 .

Two final tests with hydrogen peroxide determined if daily additions of hydrogen would maintain an $\mathrm{E}_{\mathrm{h}}$ of $+400 \mathrm{mV}$ and to determine if the $\mathrm{E}_{\mathrm{h}}$ could be maintained at about $+420 \mathrm{mV}$ and if even higher $\mathrm{E}_{\mathrm{h}}$ potentials could be achieved by increased quantities of hydrogen peroxide. Successive additions of 2.0 grams of hydrogen peroxide over the 3-day period confirmed that the $E_{h}$ was maintained between +402 and $+422 \mathrm{mV}$ with no observed change in the $\mathrm{pH}$. Addition of 4.0 grams of hydrogen peroxide produced similar $E_{h}$ value ( $+414 \mathrm{mV}$ ) as 2.0 grams of hydrogen peroxide. Since the $E_{h}$ did not respond to the higher concentration of hydrogen peroxide no further experiments with hydrogen peroxide were carried out.

A brief test was carried out to determine if ozone would serve to increase the $\mathrm{E}_{\mathrm{h}}$ and what affect, if any, it had on the $\mathrm{pH}$ of the pore water. Bubbling ozone $(\sim 6.25 \mathrm{vol} \%)$ at a flowrate of $2 \mathrm{lpm}$ resulted in an immediate increase in the $\mathrm{E}_{\mathrm{h}}$ to $+760 \mathrm{mV}$ which rose to a final reading of $+1045 \mathrm{mV}$. This is well above the target value of $+680 \mathrm{mV}$. Simultaneously with an increase in the $\mathrm{E}_{\mathrm{h}}$, the $\mathrm{pH}$ of the mixture decreased to a value of 7.44 after 75 minutes of ozone bubbling. Upon stopping the ozone bubbling, the $\mathrm{E}_{\mathrm{h}}$ rapidly decreased to $+461 \mathrm{mV}$ after 65 minutes and $+481 \mathrm{mV}$ after 205 minutes. The $\mathrm{pH}$ of the OR3 mixture measured 7.42 after 65 minutes and 7.57 after 205 minutes indicating a slow response, if any, to stopping the ozone bubbling.

Figures 3-1 and 3-2 provide plots of the measured $\mathrm{pH}$ and $\mathrm{E}_{\mathrm{h}}$ versus the date for the OR3 pore water during the various evolutions described above. 


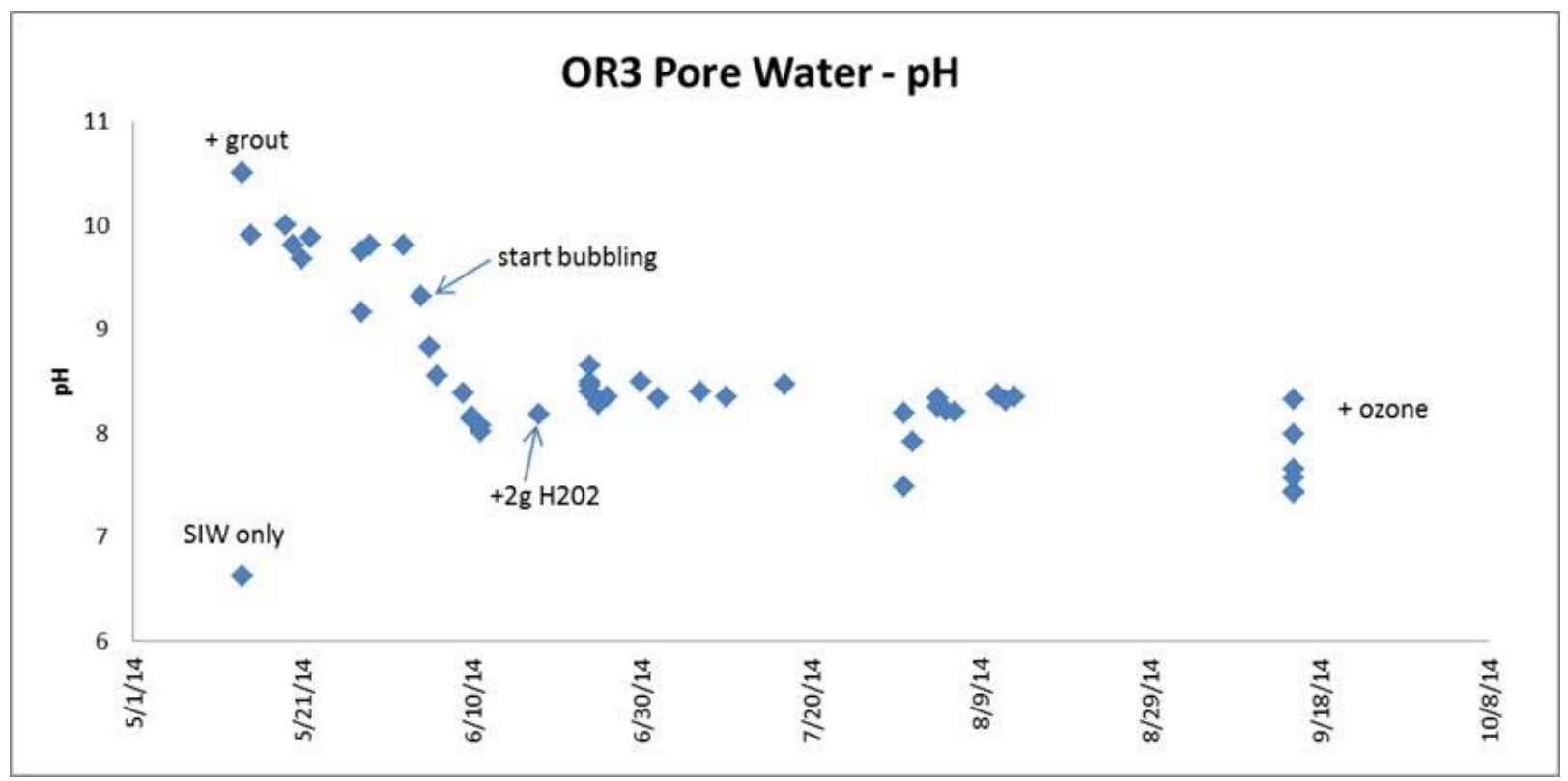

Figure 3-1. Plot of pH versus Date in the Preparation of the OR3 Pore Water

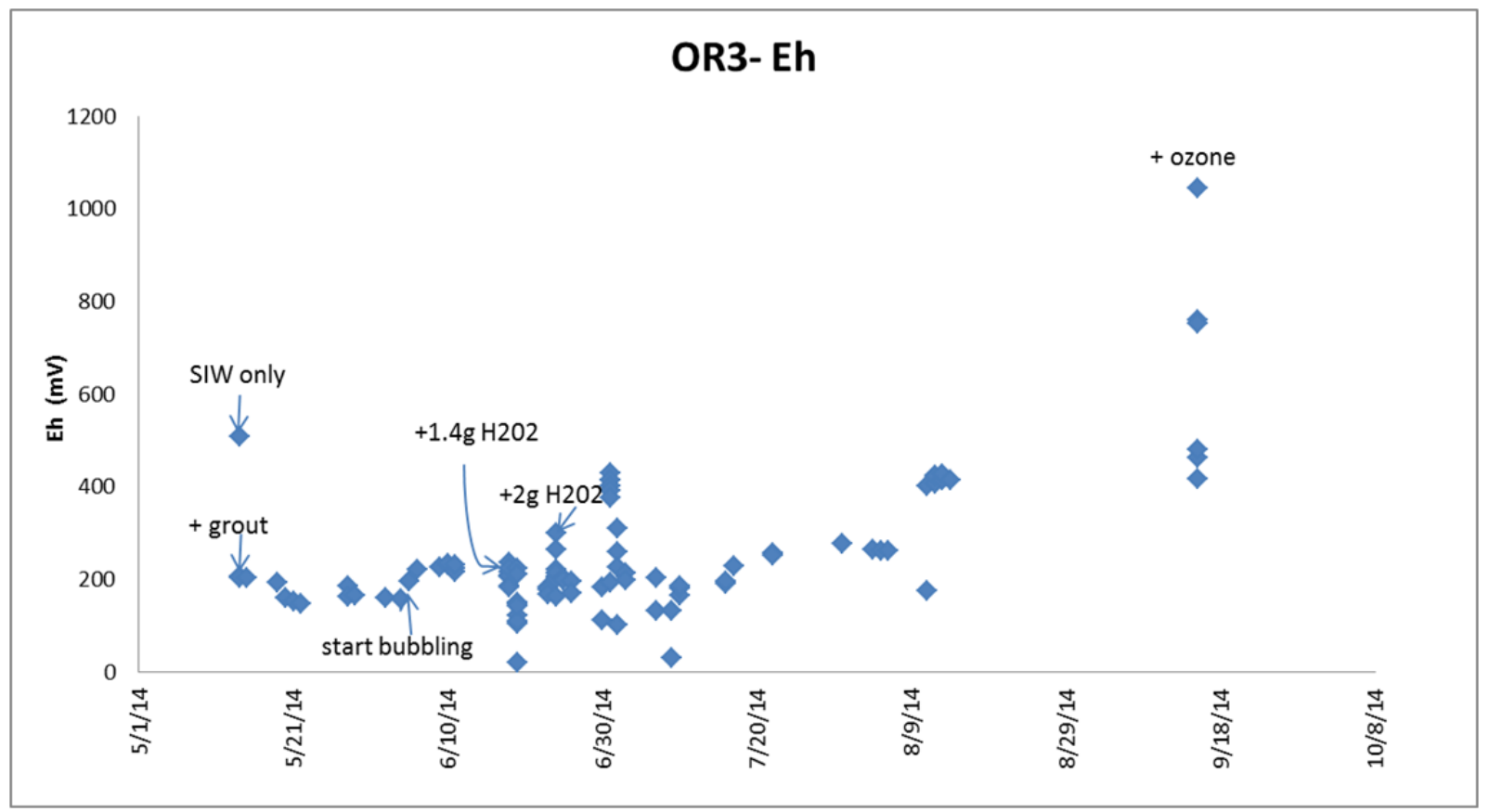

Figure 3-2. Plot of $E_{h}$ versus Date in the Preparation of the OR3 Pore Water

\subsubsection{OR2 Pore Water}

For OR2, the target $\mathrm{E}_{\mathrm{h}}$ is $+560 \mathrm{mV}$ and $\mathrm{pH}$ is 11.1. A total of 1.2 liters of the SIW and 20.0 grams of the CFS solids were placed in the glass vessel as shown on the left side of Figure 2-2. One hour after the addition of the CFS solids, the $\mathrm{pH}$ measured 11.48 and the $\mathrm{E}_{\mathrm{h}}$ measured $+135 \mathrm{mV}$. Carbon dioxide-free air was bubbled through the mixture of the SIW and CFS solids at a flowrate of $1.5 \mathrm{scfh}$. Carbon dioxide was removed to maintain a higher $\mathrm{pH}$ and limit the conversion of $\mathrm{Ca}(\mathrm{OH})_{2}$ to $\mathrm{CaCO}_{3}$. Periodic 
measurements of the $\mathrm{pH}$ and $\mathrm{E}_{\mathrm{h}}$ were made and recorded. Mixing was stopped during the off-shift time periods, but the vessel remained open to the laboratory atmosphere.

Over the next 16 days, the $\mathrm{E}_{\mathrm{h}}$ ranged from about +90 to $+135 \mathrm{mV}$ and the $\mathrm{pH} 11.76$ to 11.10 . On successive days, hydrogen peroxide additions of 2.0 and 4.0 grams, respectively, resulted in measureable increase in the $\mathrm{E}_{\mathrm{h}}$. The $\mathrm{pH}$ of the mixture measured 10.92 after the second hydrogen peroxide addition. At this time the sodium hydroxide bubbler was replaced to ensure effective removal of the carbon dioxide from the air. During this time the $\mathrm{E}_{\mathrm{h}}$ potential increased to $+155 \mathrm{mV}$.

After an additional five days, without any further hydrogen peroxide additions, the $\mathrm{E}_{\mathrm{h}}$ potential measured about $+194 \mathrm{mV}$. The increase in the $E_{\mathrm{h}}$ was attributed to a composition change in the $\mathrm{E}_{\mathrm{h}}$ standard resulting in a lower $E_{h}$. Over the next 13 days, the measured $E_{h}$ ranged from +184 to $+210 \mathrm{mV}$. Thus, we concluded that the addition of hydrogen peroxide is not effectively increasing the $E_{h}$ of the OR2 pore water. This lack of change in the $\mathrm{E}_{\mathrm{h}}$ may reflect a shorter lifetime of the peroxide in this mixture due to the higher alkalinity (higher $\mathrm{pH}$ ). ${ }^{8}$

A brief test was carried out to determine if ozone would serve to increase the $\mathrm{E}_{\mathrm{h}}$ potential and what affect, if any, it had on the $\mathrm{pH}$ of the pore water. Bubbling ozone ( $6.25 \mathrm{vol} \%)$ at a flowrate of $2 \mathrm{lpm}$ resulted in an increase in the $E_{h}$ potential to $+1039 \mathrm{mV}$. This is well above the target value of $+560 \mathrm{mV}$. Simultaneously with an increase in the $\mathrm{E}_{\mathrm{h}}$, the $\mathrm{pH}$ of the mixture decreased from 10.66 to a value of 9.61 after 180 minutes of ozone bubbling. Upon stopping the ozone bubbling, the $\mathrm{E}_{\mathrm{h}}$ potential rapidly deccreased to $+412 \mathrm{mV}$ after 140 minutes. The $\mathrm{pH}$ of the OR2 mixture measured 9.82 after 140 minutes.

Unlike hydrogen peroxide, ozone is increasing the oxidizing potential of the OR2 pore water. The degree of increase is well above the target for the OR2 pore water. However, the introduction of ozone is producing acid that is reacting with base and reducing the $\mathrm{pH}$ well below the target value of 11.1. Further testing with ozone needs to be carried out in the presence of the surrogate and actual Tank 18 solids to determine if these solids will serve to moderate the decrease in $\mathrm{pH}$ and allow the $\mathrm{pH}$ to be controlled close to the target value.

\subsubsection{RR2 Pore Water}

For RR2, the target $\mathrm{E}_{\mathrm{h}}$ is $-470 \mathrm{mV}$ and $\mathrm{pH}$ is 11.1. A total of 0.8 liters of the SIW and 13.03 grams of the ground and sieved (40 mesh) CFS solids were placed in a glass vessel similar to the vessels shown in Figure 2-2. Argon was bubbled through the mixture at a flowrate of $4.0 \mathrm{lpm}$ for 68 days. After 68 days, the $\mathrm{E}_{\mathrm{h}}$ measured $126 \mathrm{mV}$. One gram of the reducing agent, sodium dithionite, $\mathrm{Na}_{2} \mathrm{~S}_{2} \mathrm{O}_{4}$, was added to the mixture to provide a sodium dithionite concentration of 0.0071 molar. After stirring the mixture for 2.25 hours while maintaining the argon purge, the $\mathrm{E}_{\mathrm{h}}$ was measured at $-95 \mathrm{mV}$. The mixing was stopped overnight and resumed the following morning. After stirring for the mixture for 20 minutes, the $\mathrm{E}_{\mathrm{h}}$ and $\mathrm{pH}$ measured $+150 \mathrm{mV}$ and 10.43 , respectively. This indicates that the dithionite addition provided a transitory reduction in the $\mathrm{E}_{\mathrm{h}}$ of the mixture.

At this time researchers decided to make a second addition of sodium dithionite using an increased quantity of the reagent. Thus, 2.25 grams of sodium dithionite was added to the mixture to provide a sodium dithionite concentration of 0.016 molar. After stirring the mixture for three hours, the $\mathrm{E}_{\mathrm{h}}$ and $\mathrm{pH}$ of the mixture measured $+110 \mathrm{mV}$ and 9.20 , respectively. The second and larger addition produced a much smaller decrease in the $\mathrm{E}_{\mathrm{h}}$ and reduced the $\mathrm{pH}$ of the mixture from 10.43 to 9.20 . This result suggests the addition of sodium dithionite will not likely achieve the target $E_{h}$ value of $-470 \mathrm{mV}$. 


\subsection{Conclusions}

Based on the findings reported in this document the authors conclude the following.

- Pore water $E_{\mathrm{h}}$ potentials produced in these studies upon contact of synthetic infiltration water with surrogate tank closure solids are lower than those used in PA modeling. This suggests that in short-term experiments, kinetic controls on the $E_{h}$ values of the synthetic pore waters in contact with grout solids dominate over the equilibrium controls assumed in the PA waste release modeling.

- The zero head-space method appears viable for testing the release of radionuclides from solids under reducing conditions, but not under oxidizing conditions due to oxygen depletion.

- Researchers must account for the alkalinity and redox potential of the tank waste solids to ensure target $\mathrm{pH}$ and $\mathrm{E}_{\mathrm{h}}$ values will be achieved in radionuclide release testing.

- The addition of hydrogen peroxide will increase the $\mathrm{E}_{\mathrm{h}}$ potentials of OR3, but not OR2 pore water to about $+420 \mathrm{mV}$ and decrease the $\mathrm{pH}$ by about one $\mathrm{pH}$ unit. These changes are transitory due to the decomposition of peroxide in alkaline solutions.

- The addition of ozone increases the potentials of OR2 and OR3 pore waters above $+1000 \mathrm{mV}$ as long as excess ozone is present. The addition of ozone generates acid which lowers the $\mathrm{pH}$ of the pore OR2 and OR3 waters.

- Under moderate reducing conditions, the quantity of Pu and $\mathrm{U}$ dissolved from the surrogate Tank 18 solids increased in pore water solutions that feature less reducing $\mathrm{E}_{\mathrm{h}}$ and lower $\mathrm{pH}$ values.

- The presence of cement solids in the leaching tests generally reduced the dissolution of $\mathrm{Pu}$ and $\mathrm{U}$ from the surrogate Tank 18 solids.

\subsection{Recommendations}

Based on the findings and conclusions summarized in this technical report, the authors recommend that leachate testing with surrogate materials be continued and finalized prior to initiating testing with actual waste residuals. Testing with actual tank waste solids would be expected to provide additional information regarding the residual waste solubility assumptions used in the Tank Farm Performance Assessments' waste release models. The following specific actions are recommended with respect to continued waste release testing.

- Reduce the lower quantifiable limit for detection of Pu in leachates by increasing the size of the aliquot and employ longer alpha counting times.

- Determine the effect, if any; of the syringe filter pore size on $\mathrm{Pu} / \mathrm{U}$ concentrations in leachates to ensure that the measured $\mathrm{Pu} / \mathrm{U}$ concentrations reflect only dissolved species.

- Complete experimental studies evaluating the use of ozone to increase oxidizing $\mathrm{E}_{\mathrm{h}}$ potentials and the use of dithionite, sulfide and ferrous ion to increase reducing $E_{h}$ potentials so that surrogate pore waters have $\mathrm{E}_{\mathrm{h}}$ potentials at the targeted values.

- Test production of pore waters using only solid phases believed to be controlling the $\mathrm{pH}$ and $\mathrm{E}_{\mathrm{h}}$ at equilibrium conditions. 


\subsection{References}

1. M. E. Denham and M. R. Millings, "Evolution of Chemical Conditions and Estimated Solubility Controls on Radionuclides in the Residual Waste Layer During Post-Closure Aging of High-Level Waste Tanks”, SRNL-STI-2012-00404, August 2012.

2. K. H. Rosenberger, "Savannah River Site Liquid Waste Facilities Performance Assessment Maintenance Program FY2014 Implementation Plan”, SRR-CWDA-2013-00133, January 2014.

3. Technical Task Request, "Tank waste testing to evaluate residual waste solubility assumptions used in the Tank Farm PAs”, HLE-TTR-2013-002, rev. 1, February 5, 2014.

4. R. N. Strom, and D.S. Kaback, "SRP Baseline Hydrogeologic Investigation: Aquifer Characterization Groundwater Geochemistry of the Savannah River Site and Vicinity (U)”, WSRC-RP-92-450, 1992.

5. D. B. Stefanko and C. A. Langton, "Tanks 18 and 19-F Structural Flowable Grout Fill Material Evaluation and Recommendations”, SRNL-STI-2011-00551, Rev. 1, April 2011.

6. L. N. Oji, D. Diprete, and D. R. Click, “Characterization of the Tank 18F Samples”, SRNL-STI2009-00625, Rev. 0, December 2009.

7. L. N. Oji, D. Diprete, and C. J. Coleman, “Characterization of Additional Tank 18F Samples”, SRNL-STI-2010-00386, Rev. 0, September 2010.

8. F. A. Cotton and G. Wilkinson Advanced Inorganic Chemistry - A Comprehensive Text, $3^{\text {rd }}$ Edition, Interscience Publishers, New York, 1972, p. 416. 


\section{Distribution:}

S. L. Marra, 773-A

T. B. Brown, 773-A

D. H. McGuire, 999-W

S. D. Fink, 773-A

C. C. Herman, 773-A

D. T. Hobbs, 773-A

E. N. Hoffman, 999-W

F. M. Pennebaker, 773-42A

W. R. Wilmarth, 773-A

K. H. Rosenberger,705-1C

L. B. Romanowski,705-1C

M. H. Layton, 705-1C

P. R. Jackson, DOE-SR, 703-46A

J. A. Crenshaw, 703-46A

K. M. L. Taylor-Pashow, 773-A

Records Administration (EDWS)
B. T. Butcher, 773-43A

D. A. Crowley, 773-43A

G. P. Flach, 773-42A

L. L. Hamm, 703-41A

R. A. Hiergesell, 773-43A

G. K. Humphries, 730-4B

D. I. Kaplan, 773-43A

D. Li, 773-42A

D. H. Miller, 999-W

M. A. Phifer, 773-42A

K. A. Roberts, 773-43A

R. R. Seitz, 773-43A

F. G. Smith, III 703-41A

G. A. Taylor, 773-43A

M. E. Denham, 773-42A 